\title{
EXPERIMENTAL STUDY ON SHEAR STRENGTH BEHAVIOR OF SUPER PLASTICIZED FIBER REINFORCED CONCRETE BEAMS WITH HIGH REACTIVE METAKAOLIN
}

\author{
C N Sushma ${ }^{1}$, R.L Ramesh ${ }^{2}$, Nagaraja P.S ${ }^{3}$ \\ ${ }^{1} P$ G Student, Department of Civil Engineering, S.J.B Institute of Technology, Bangalore-60, India \\ ${ }^{2}$ Associate professor, Department of Civil Engineering, S.J.B Institute of Technology, Bangalore-60, India \\ ${ }^{3}$ Professor, Faculty of Civil Engineering, UVCE, Bangalore-56, India.
}

\begin{abstract}
Experimental investigation is carried out to study the behavior of Metakaolin reinforced concrete in comparison to fly ash reinforced concrete with and without steel fibers on compressive strength and under shear strength. The weakness in tension of conventional concrete is overcome by incorporating steel fibers into the matrix while the Metakaolin and Fly ash can increase many properties of concrete and also reduces the cementing consumption. 12 beams of length $1500 \mathrm{~mm}$, breadth $150 \mathrm{~mm}$ and depth $200 \mathrm{~mm}$ having 4-12 mm diameter bars as tension reinforcement and $2 \mathrm{~L}, 8 \mathrm{~mm}$ diameter bars spaced at $130 \mathrm{~mm} \mathrm{c} / \mathrm{c}$ as stirrups were casted and cured for 28 days and tested under two point loading applied at 1/3 span points.
\end{abstract}

Keywords: Cement, Fly Ash, Metakaolin, Super Plasticizer, Steel Fibres, Shear Strength.

\section{INTRODUCTION}

Concrete is one of the most extensively used construction materials in the world, with two billion tons placed worldwide each year. In reviewing technology advances through the centuries it is evident that material developments place a key role. Considerable efforts are still being made in every part of the world to develop new construction materials. In the construction industry concrete technology is heading towards entirely a new era by the use of supplementary cementitious materials such as Fly ash, Metakaolin, Rise husk ash and silica fume in concrete.

While conventional concrete has poor strength, low resistant to tensile cracking, so that its capacity to absorb energy is limited. The weakness in tension is conventionally overcome by strengthening their matrix with steel and more recently by reinforcing with fibrous materials. Concrete when mixed with fibres, give fibrous concrete. The mechanical property of fibrous concrete is superior to that of ordinary concrete. Fly ash and Metakaolin will be evaluated for use as supplementary cementitious material in cement based system, the performance of Fly ash and Metakaolin mixtures will be compared to controlled mixtures and mixtures incorporating Metakaolin as partial replacement for cement.

The manifold benefits of usage of Metakaolin, Fly ash and Steel Fibres in concrete are now well recognised. To improve the usage of Fly ash and Steel Fibres in structural concrete studies on aspects such as Compressive strength of Metakaolin Fly ash fiber reinforced concrete are to be undertaken which will spread its usage.
Hence an experimental investigation is carried out to understand the behaviour of conventional concrete and replacement of cement by supplementary cementitious materials such as Metakaolin and Fly ash in various combinations with and without steel fibres. A comparative study is made on shear strength.

The following are the specimens considered for the present study:

1. Two reinforced concrete beams of mix M-25. (C.C)

2. Two beams of consisting of M-25 with $50 \mathrm{~kg} / \mathrm{m} 3$ of steel fiber concrete (CFB)

3. Two beams of M-25 with cement replaced have been replaced by $10 \%$ of fly ash ( CF)

4. Two beams of M-25 with cement replaced have been replaced by $10 \%$ of fly ash along with $50 \mathrm{~kg} / \mathrm{m} 3$ of steel fiber concrete(CFF)

5. Two beams of M-25 with cement replaced have been replaced by $10 \%$ of Metakaolin (CMK).

6. Two beams of M-25 with cement replaced have been replaced by $10 \%$ of Metakaolin along with $50 \mathrm{~kg} / \mathrm{m} 3$ of steel fiber concrete(CMKF)

\section{METHODOLOGY}

\subsection{General}

The properties of various materials used throughout the experimental work are explained. Also the details of method of casting and testing of beams are explained. 


\subsection{MATERIALS USED}

a) Cement: Ordinary Portland cement of 53 Grade conforming to IS: 12269-1987 has been used. The specific gravity of cement is 3.1 and fineness is $5 \%$.

b) Fine aggregate: Locally available clean river sand passing IS: 480 sieve has been used. Sand conforms to Zone III as per the specifications of IS 383: 1970. The specific gravity of sand is 2.64 and fineness modulus is 2.71 .

c) Coarse aggregate: Crushed granite of $20 \mathrm{~mm}$ maximum size and retained on IS 480 sieve has been used. Specific gravity of coarse aggregate is 2.7 and fineness modulus is 6.816 .

d) Water: Clean portable water is used for mixing and curing.

e) Reinforcement : Untensioned high yield strength bars conforming to IS: 1786 (Grade Fe 415) has been used.

f) Steel fibers: Crimped end wire of length $36 \mathrm{~mm}$, diameter $45 \mathrm{~mm}$, Aspect ratio of 80 has been used.

g) Metakaolin : The average particle size is $1.5 \mathrm{~mm}$. The specific gravity is 2.5 . The bulk density is $300 \pm 30$ $\mathrm{gm} /$ liter.

h) Fly ash: The fineness is $380 \mathrm{~m}^{3} / \mathrm{kg}$, lime reactivity is $85.2 \%$, and dry shrinkage is $0.048 \%$.

i) Admixture: Super plasticizer Conplast SP-430 a product from FOSROC chemicals conforming to IS: 9103 has been used.

Beams of length $1500 \mathrm{~mm}$, breadth $150 \mathrm{~mm}$ and depth $200 \mathrm{~mm}$ having $4-12 \mathrm{~mm}$ diameter bars as tension reinforcement and 2L $8 \mathrm{~mm}$ diameter bars spaced at $130 \mathrm{~mm}$ $\mathrm{c} / \mathrm{c}$ as stirrups were casted and cured for 28 days and tested under two point loading applied at $1 / 3$ span points.

\section{RESULTS OBTAINED BY THE INVESTIGATION}

The test results of compressive strength of design mix M-25 on standard $150 \mathrm{~mm}$ cubes at 7 and 28 days curing periods obtained are given below in the table 1 and are graphically represented in figures 1 and 2.

Table 1:

\begin{tabular}{|c|c|c|c|}
\hline \multirow{2}{*}{ Mix } & \multirow{2}{*}{$\begin{array}{c}\text { MIX } \\
\text { DESCRIPTION }\end{array}$} & \multicolumn{2}{|c|}{$\begin{array}{c}\text { Compressive Strength } \\
\text { of Cube in N/mm2 }\end{array}$} \\
\cline { 3 - 4 } & & 7 days & 28 Days \\
\hline CC & Control Concrete & 27.55 & 32.00 \\
\hline CF & Fly Ash Concrete & 23.33 & 30.00 \\
\hline CMK & Metakaolin Concrete & 28.51 & 40.88 \\
\hline CFB & $\begin{array}{c}\text { Control Concrete } \\
\text { With Steel Fibers }\end{array}$ & 30.00 & 37.33 \\
\hline CFF & $\begin{array}{c}\text { Fly Ash Concrete } \\
\text { With Steel Fibers }\end{array}$ & 27.77 & 35.11 \\
\hline CMKF & $\begin{array}{c}\text { Metakaolin Concrete } \\
\text { With Steel Fibers }\end{array}$ & 33.33 & 43.50 \\
\hline
\end{tabular}

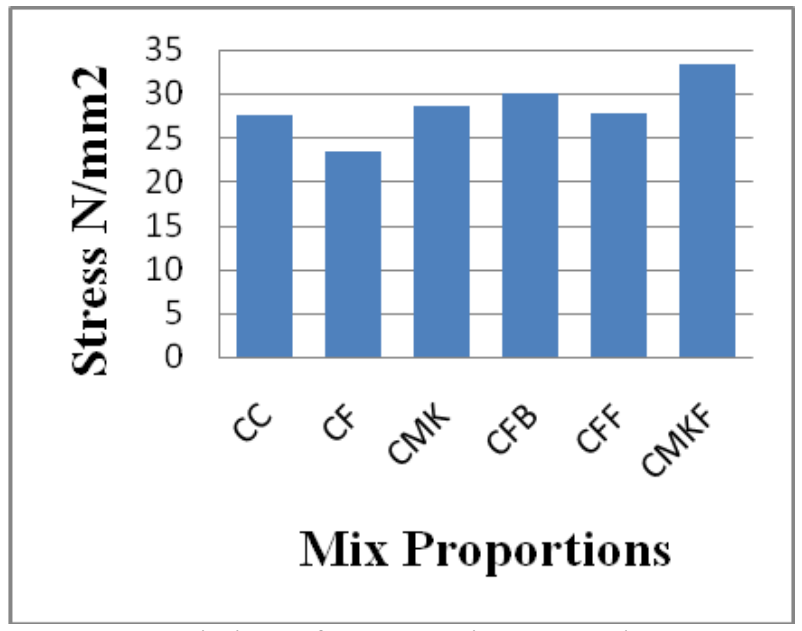

Figure 1- Variation Of Compressive Strength For 7 Days

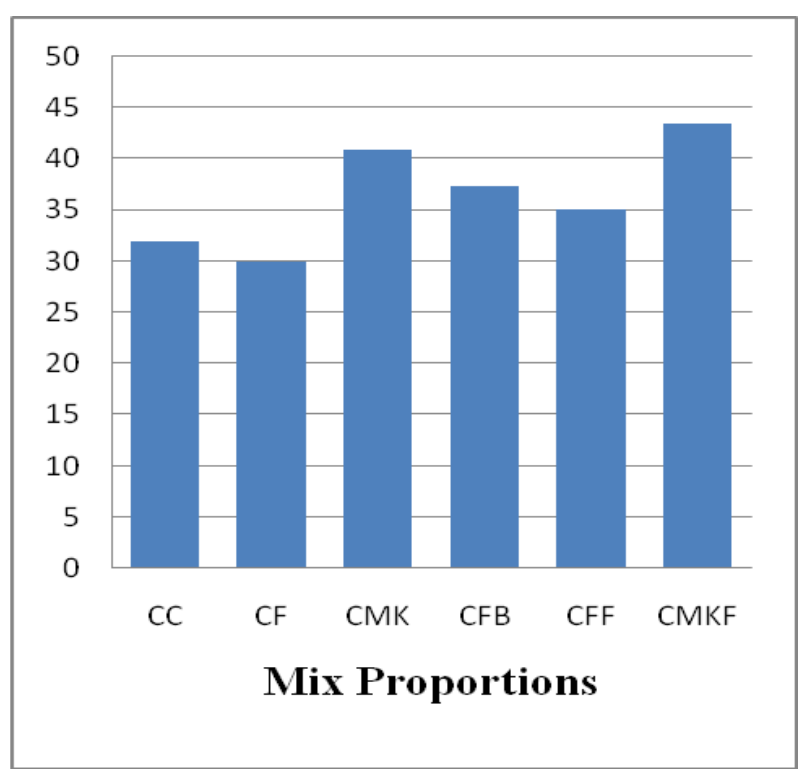

Figure 2- Variation of Compressive Strength for 28 Days

Results of shear tests indicating salient loads for control concrete, fly ash and metakaolin concrete beam specimen are shown in table 2.

Table 2:

\begin{tabular}{|l|c|c|c|}
\hline Beam no & $\begin{array}{l}\text { Cube } \\
\text { Compressive } \\
\text { Strength (fck) } \\
\text { N/mm2 }\end{array}$ & $\begin{array}{l}\text { First crack } \\
\text { load KN }\end{array}$ & $\begin{array}{l}\text { Ultimate } \\
\text { Load in KN }\end{array}$ \\
\hline $\begin{array}{l}\text { B1 } \\
\text { CC }\end{array}$ & 32.00 & 29.43 & 88.2 \\
\hline $\begin{array}{l}\text { B2 } \\
\text { CFB }\end{array}$ & 37.33 & 34.33 & 122.5 \\
\hline $\begin{array}{l}\text { B3 } \\
\text { CF }\end{array}$ & 30.00 & 24.52 & 73.5 \\
\hline $\begin{array}{l}\text { B4 } \\
\text { CFF }\end{array}$ & 35.11 & 29.43 & 102.9 \\
\hline $\begin{array}{l}\text { B5 } \\
\text { CMK }\end{array}$ & 40.88 & 3.24 & 93.1 \\
\hline $\begin{array}{l}\text { B6 } \\
\text { CMKF }\end{array}$ & 43.5 & 44.145 & 137.7 \\
\hline
\end{tabular}


Table 3: Strain Distribution under a Load for Beam B1 (CC):

\begin{tabular}{|l|l|l|l|l|l|l|}
\hline $\begin{array}{l}\text { Load } \\
\text { in KN }\end{array}$ & $\begin{array}{l}\text { Depth } \\
\text { of beam }\end{array}$ & 0 & 50 & 100 & 150 & 200 \\
\hline 0 & $\begin{array}{l}\text { Strain in } \\
\times 10^{-4}\end{array}$ & 0 & 0 & 0 & 0 & 0 \\
\hline 10 & & -17.58 & -14.2 & 0.28 & 14.29 & 17.42 \\
\hline 20 & & -19.47 & -14.58 & 0.32 & 14.73 & 19.38 \\
\hline 30 & & -21.38 & -15.45 & 0.33 & 15.53 & 21.25 \\
\hline 40 & & -23.67 & -17.39 & 0.35 & 17.21 & 23.61 \\
\hline 50 & & -25.65 & -18.63 & 0.34 & 18.51 & 25.86 \\
\hline 60 & & -27.53 & -19.54 & 0.33 & 19.47 & 27.55 \\
\hline 70 & & -29.58 & -22.66 & 0.32 & 22.63 & 29.51 \\
\hline 80 & & -32.24 & -25.74 & 0.31 & 25.45 & 32.38 \\
\hline 90 & & -34.79 & -27.59 & 0.3 & 27.23 & 34.73 \\
\hline
\end{tabular}

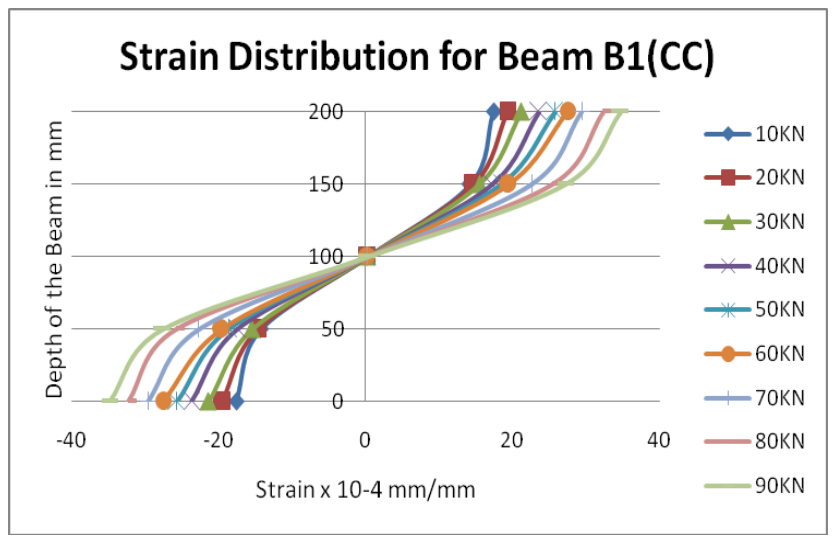

Table 4: Strain Distribution under a Load for Beam B2

\begin{tabular}{|l|l|l|l|l|l|l|}
\hline $\begin{array}{l}\text { Load } \\
\text { i } \\
\text { KN }\end{array}$ & $\begin{array}{l}\text { Depth } \\
\text { of } \\
\text { beam }\end{array}$ & 0 & 50 & 100 & 150 & 200 \\
\hline 0 & $\begin{array}{l}\text { Strain } \\
\text { in } \\
\text { x10-4 }\end{array}$ & 0 & 0 & 0 & 0 & 0 \\
\hline 10 & & -10.53 & -5.85 & 0.3 & 14.59 & 17.52 \\
\hline 20 & & -11.49 & -6.4 & 0.32 & 14.83 & 19.38 \\
\hline 30 & & -12.35 & -7.23 & 0.33 & 15.73 & 21.35 \\
\hline 40 & & -13.52 & -8.52 & 0.34 & 17.51 & 23.71 \\
\hline 50 & & -14.92 & -9.53 & 0.35 & 18.81 & 25.76 \\
\hline 60 & & -16.51 & -10.63 & 0.33 & 19.67 & 27.55 \\
\hline 70 & & -18.49 & -12.52 & 0.32 & 22.83 & 29.51 \\
\hline 80 & & -20.59 & -14.6 & 0.33 & 24.55 & 32.38 \\
\hline 90 & & -21.89 & -15.72 & 0.31 & 25.55 & 33.43 \\
\hline 100 & & -22.92 & -16.76 & 0.3 & 26.3 & 34.73 \\
\hline 110 & & -23.67 & -18.53 & 0.29 & 27.2 & 35.68 \\
\hline 120 & & -25.65 & -19.74 & 0.28 & 28.43 & 36.2 \\
\hline 130 & & -27.53 & -20.46 & 0.27 & 29.53 & 37.53 \\
\hline
\end{tabular}

\section{Strain Distribution for Beam B2(CCF)}

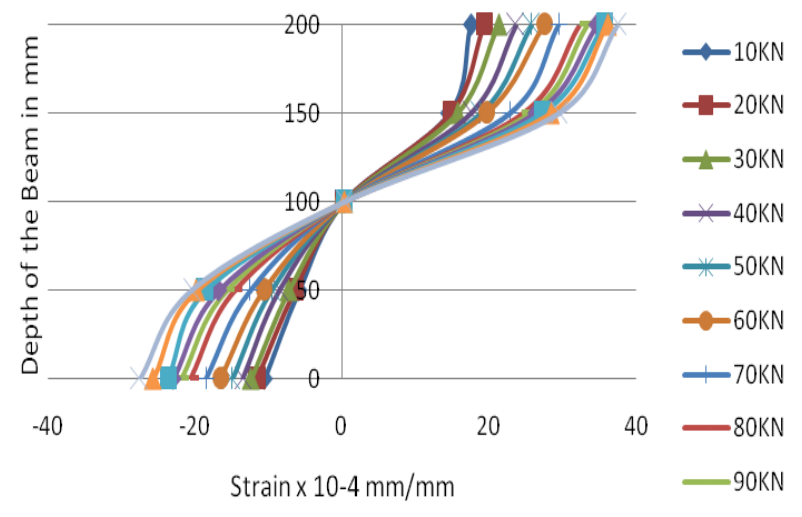

Table 5: Strain Distribution under a Load for Beam B3

\begin{tabular}{|l|l|l|l|l|l|l|}
\hline $\begin{array}{l}\text { Load } \\
\text { in } \\
\text { KN }\end{array}$ & $\begin{array}{l}\text { Depth } \\
\text { of } \\
\text { beam }\end{array}$ & 0 & 50 & 100 & 150 & 200 \\
\hline 0 & $\begin{array}{l}\text { Strain } \\
\text { in } \\
\text { x10-4 }\end{array}$ & 0 & 0 & 0 & 0 & 0 \\
\hline 10 & & -20.25 & -17.25 & -0.07 & 17.44 & 20.35 \\
\hline 20 & & -22.49 & -17.96 & -0.06 & 17.91 & 22.44 \\
\hline 30 & & -24.71 & -18.57 & -0.025 & 18.83 & 24.12 \\
\hline 40 & & -26.91 & -20.49 & -0.01 & 20.45 & 26.33 \\
\hline 50 & & -28.48 & -21.21 & -0.065 & 21.82 & 28.7 \\
\hline 60 & & -30.36 & -22.85 & -0.04 & 22.15 & 30.26 \\
\hline 70 & & -31.56 & -23.84 & -0.015 & 23.36 & 31.76 \\
\hline 80 & & -32.36 & -24.25 & -0.023 & 24.25 & 32.52 \\
\hline
\end{tabular}

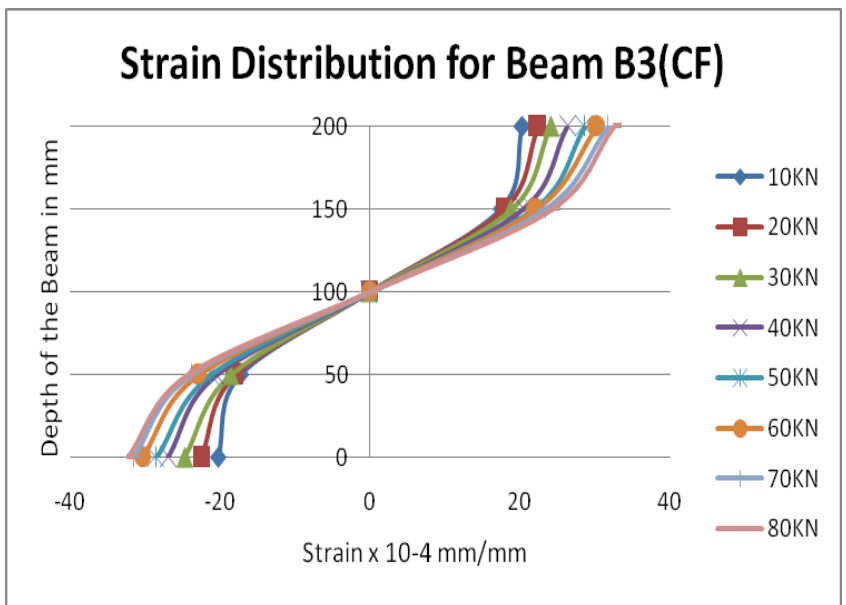


Table 6: Strain Distribution under a Load for Beam B4 (CFF):

\begin{tabular}{|l|l|l|l|l|l|l|}
\hline $\begin{array}{l}\text { Load } \\
\text { in } \\
\text { KN }\end{array}$ & $\begin{array}{l}\text { Depth } \\
\text { of } \\
\text { beam }\end{array}$ & 0 & 50 & 100 & 150 & 200 \\
\hline 0 & $\begin{array}{l}\text { Strain } \\
\text { in } \\
\times 10^{-4}\end{array}$ & 0 & 0 & 0 & 0 & 0 \\
\hline 10 & & -17.5 & -13.4 & 0.07 & 13.2 & 17.43 \\
\hline 20 & & -19.82 & -14.6 & 0.09 & 14.95 & 19.34 \\
\hline 30 & & -22.53 & -15.86 & 0.14 & 15.44 & 22.2 \\
\hline 40 & & -25.73 & -17.31 & 0.02 & 17.28 & 25.18 \\
\hline 50 & & -28.4 & -18.43 & 0.01 & 18.8 & 28.77 \\
\hline 60 & & -30.81 & -19.57 & 0.04 & 19.3 & 30.55 \\
\hline 70 & & -32.58 & -22.76 & 0.05 & 22.47 & 32.53 \\
\hline 80 & & -35.21 & -25.47 & 0.06 & 25.71 & 35.58 \\
\hline 90 & & -36.43 & -26.32 & 0.07 & 26.23 & 36.88 \\
\hline 100 & & -37.58 & -27.84 & 0.08 & 27.45 & 37.65 \\
\hline 110 & & -38.23 & -28.56 & 0.09 & 28.65 & 38.83 \\
\hline & & & & & & \\
\hline
\end{tabular}

\section{Strain Distribution for Beam B4(CFF)}

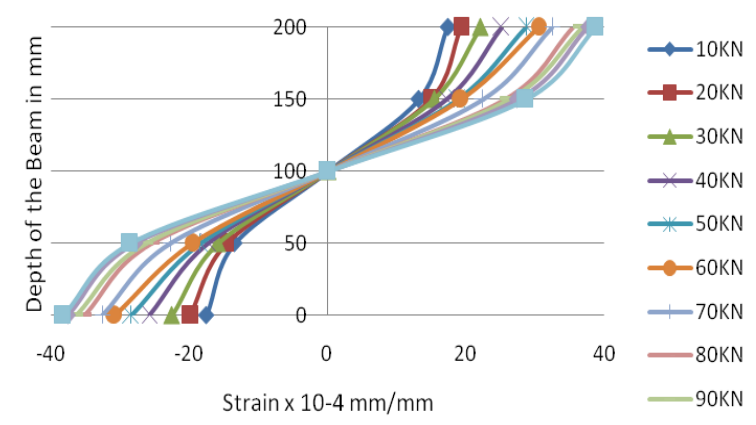

Table 7: Strain Distribution under a Load for Beam B5 (CMK):

\begin{tabular}{|l|l|l|l|l|l|l|}
\hline $\begin{array}{l}\text { Load } \\
\text { in } \\
\text { KN }\end{array}$ & $\begin{array}{l}\text { Depth } \\
\text { of } \\
\text { beam }\end{array}$ & 0 & 50 & 100 & 150 & 200 \\
\hline 0 & $\begin{array}{l}\text { Strain } \\
\text { in } \\
\text { x } 10^{-4}\end{array}$ & 0 & 0 & 0 & 0 & 0 \\
\hline 10 & & -14.27 & -11.87 & 0.35 & 11.79 & 14.68 \\
\hline 20 & & -16.82 & -12.84 & 0.37 & 12.93 & 16.32 \\
\hline 30 & & -18.96 & -13.9 & 0.38 & 13.42 & 18.65 \\
\hline 40 & & -20.45 & -14.75 & 0.39 & 14.55 & 20.54 \\
\hline 50 & & -22.96 & -16.41 & 0.4 & 16.1 & 22.87 \\
\hline 60 & & -24.5 & -17.32 & 0.41 & 19.14 & 26.4 \\
\hline 70 & & -26.64 & -19.7 & 0.4 & 19.41 & 26.4 \\
\hline 80 & & -27.79 & -20.19 & 0.38 & 22.51 & 27.49 \\
\hline 90 & & -29.29 & -22.99 & 0.36 & 22.1 & 29.33 \\
\hline 100 & & -30.27 & -23.9 & 0.35 & 23.8 & 31.63 \\
\hline
\end{tabular}

\section{Strain Distribution for Beam B5(CMK)}



Table 8: Strain Distribution under a Load for Beam B6 (CMKF):

\begin{tabular}{|l|l|l|l|l|l|l|}
\hline $\begin{array}{l}\text { Load } \\
\text { in } \\
\text { KN }\end{array}$ & $\begin{array}{l}\text { Depth } \\
\text { of } \\
\text { beam }\end{array}$ & 0 & 50 & 100 & 150 & 200 \\
\hline 0 & $\begin{array}{l}\text { Strain } \\
\text { in } \\
\text { x10-4 }\end{array}$ & 0 & 0 & 0 & 0 & 0 \\
\hline 10 & & -7.16 & -4.14 & 0.51 & 3.68 & 7.43 \\
\hline 20 & & -8.16 & -4.36 & 0.53 & 4.74 & 8.64 \\
\hline 30 & & -9.51 & -4.89 & 0.55 & 4.88 & 9.32 \\
\hline 40 & & -10.335 & -6.7 & 0.56 & 5.78 & 10.33 \\
\hline 50 & & -11.46 & -7.4 & 0.58 & 6.91 & 11.14 \\
\hline 60 & & -12.68 & -8.52 & 0.6 & 8.22 & 12.17 \\
\hline 70 & & -14.8 & -9.11 & 0.62 & 8.99 & 13.89 \\
\hline 80 & & -14.59 & -9.62 & 0.61 & 9.36 & 14.19 \\
\hline 90 & & -15.79 & -10.51 & 0.59 & 10.51 & 15.89 \\
\hline 100 & & -16.89 & -11.3 & 0.57 & 11.4 & 16.39 \\
\hline 110 & & -17.25 & -15.65 & 0.55 & 11.58 & 17.47 \\
\hline 120 & & -18.48 & -17.77 & 0.54 & 12.23 & 18.59 \\
\hline 130 & & -19.53 & -19.89 & 0.53 & 13.36 & 19.26 \\
\hline 140 & & -20.32 & -23.13 & 0.51 & 14.27 & 20.82 \\
\hline
\end{tabular}

\section{Strain Distribution for Beam B6(CMKF)}

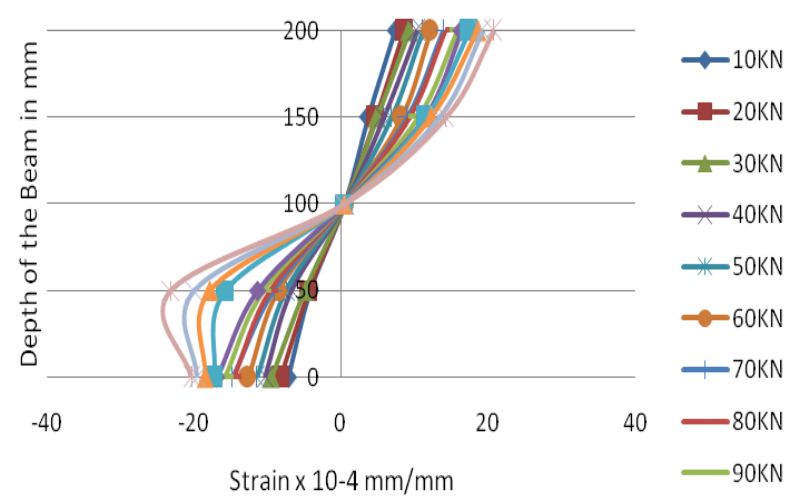




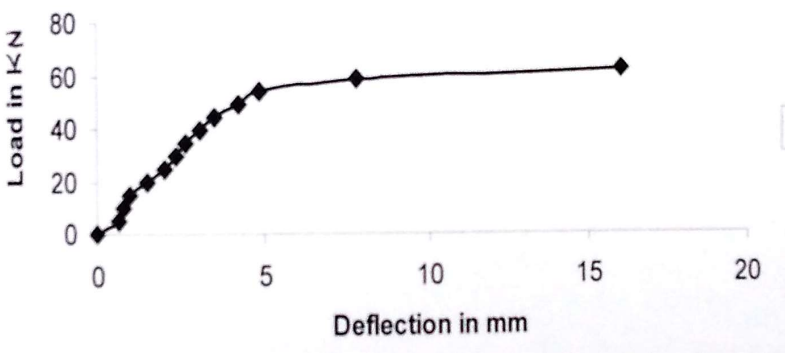

Figure 3: Load Deflection Behavior

Table 9: Theoretical and Experimental First Cracking Loads:

\begin{tabular}{|l|l|l|l|}
\hline $\begin{array}{l}\text { Mix } \\
\text { description }\end{array}$ & $\begin{array}{l}\text { Theoretical } \\
\text { cracking } \\
\text { load KN }\end{array}$ & $\begin{array}{l}\text { Experimental } \\
\text { cracking load } \\
\text { KN }\end{array}$ & ratio \\
\hline $\begin{array}{l}\text { Control } \\
\text { Concrete }\end{array}$ & 14.95 & 29.43 & 1.968 \\
\hline $\begin{array}{l}\text { Control } \\
\text { Concrete+ } \\
\text { steel fibers }\end{array}$ & 15.69 & 34.33 & 2.188 \\
\hline $\begin{array}{l}\text { CC, Mix } \\
\text { M25+10\% } \\
\text { of Fly Ash }\end{array}$ & 11.47 & 24.525 & 2.138 \\
\hline $\begin{array}{l}\text { CC, Mix } \\
\text { M25+10\% } \\
\text { of Fly Ash+ } \\
\text { steel fibers }\end{array}$ & 15.15 & 29.43 & 1.892 \\
\hline $\begin{array}{l}\text { CC, Mix } \\
\text { M25+10\% } \\
\text { of } \\
\text { Metakaolin }\end{array}$ & 16.81 & 39.24 & 2.333 \\
\hline $\begin{array}{l}\text { CC, Mix } \\
\text { M25+10\% } \\
\text { of } \\
\text { Metakaolin } \\
+ \text { steel fibers }\end{array}$ & 17.63 & 44.145 & \\
\hline & & & \\
\hline & & & \\
\hline & & & \\
\hline & & & \\
\hline & & & \\
\hline
\end{tabular}

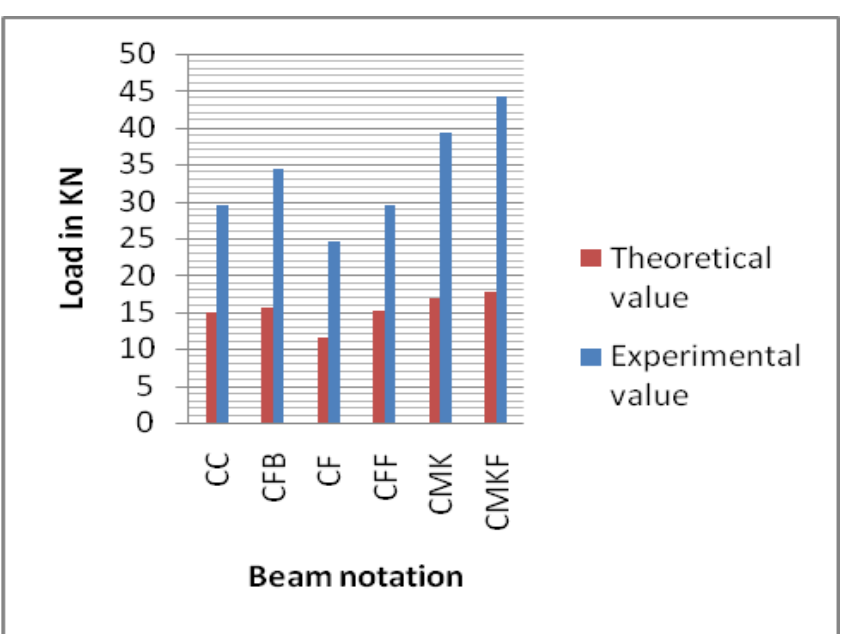

Figure 4- Theoretical and Experimental Cracking Loads of all Concrete Beams
Table 10: Test Results of Cracks Spacing and Number of Cracks:

\begin{tabular}{|l|l|l|l|l|}
\hline $\begin{array}{l}\text { Mix } \\
\text { description }\end{array}$ & $\begin{array}{l}\text { Total } \\
\text { no of } \\
\text { cracks }\end{array}$ & $\begin{array}{l}\text { Number } \\
\text { of shear } \\
\text { zone } \\
\text { cracks }\end{array}$ & $\begin{array}{l}\text { Max. } \\
\text { crack } \\
\text { spacing } \\
\text { in mm }\end{array}$ & $\begin{array}{l}\text { Average } \\
\text { spacing } \\
\text { in mm }\end{array}$ \\
\hline $\begin{array}{l}\text { Control } \\
\text { Concrete }\end{array}$ & 10 & 4 & 125 & 85 \\
\hline $\begin{array}{l}\text { Control } \\
\text { Concrete+ } \\
\text { steel fibers }\end{array}$ & 9 & 7 & 110 & 80 \\
\hline $\begin{array}{l}\text { CC, Mix } \\
\text { M25+10\% } \\
\text { of Fly Ash }\end{array}$ & 11 & 7 & 110 & 78 \\
\hline $\begin{array}{l}\text { CC, Mix } \\
\text { M25+10\% } \\
\text { of Fly } \\
\text { Ash+ steel } \\
\text { fibers }\end{array}$ & & 5 & 105 & 80 \\
\hline $\begin{array}{l}\text { CC, Mix } \\
\text { M25+10\% } \\
\text { of } \\
\text { Metakaolin }\end{array}$ & & 7 & 100 & 75 \\
\hline $\begin{array}{l}\text { CC, Mix } \\
\text { M25+10\% } \\
\text { of } \\
\text { Metakaolin } \\
+ \\
\text { fibers steel }\end{array}$ & 9 & 5 & & \\
\hline & & & & \\
\hline & & & & \\
\hline
\end{tabular}

Table 11: Analysis Result of Theoretical And Ultimate Loads:

\begin{tabular}{|l|l|l|l|}
\hline Mix description & $\begin{array}{l}\text { Theoretical } \\
\text { load in KN }\end{array}$ & $\begin{array}{l}\text { Experimenta } \\
1 \text { load in KN }\end{array}$ & Ratio \\
\hline $\begin{array}{l}\text { Control } \\
\text { Concrete }\end{array}$ & 49.05 & 88.2 & 1.798 \\
\hline $\begin{array}{l}\text { Control } \\
\text { Concrete+ steel } \\
\text { fibers }\end{array}$ & 51.487 & 122.5 & 2.37 \\
\hline $\begin{array}{l}\text { CC, Mix } \\
\text { M25+10\% of } \\
\text { Fly Ash }\end{array}$ & 48.63 & 73.5 & 1.511 \\
\hline $\begin{array}{l}\text { CC, Mix } \\
\text { M25+10\% of }\end{array}$ & 49.2 & 102.9 & 2.09 \\
$\begin{array}{l}\text { Fly Ash+ steel } \\
\text { fibers }\end{array}$ & & & \\
\hline $\begin{array}{l}\text { CC, Mix } \\
\text { M25+10\% of } \\
\text { Metakaolin }\end{array}$ & 52.394 & 98.1 & 1.872 \\
\hline $\begin{array}{l}\text { CC, Mix } \\
\text { M25+10\% of } \\
\text { Metakaolin + } \\
\text { steel fibers }\end{array}$ & & 137.2 & 2.55 \\
\hline
\end{tabular}






Figure 5- Theoretical And Experimental Ultimate Loads Of All Concrete Beams

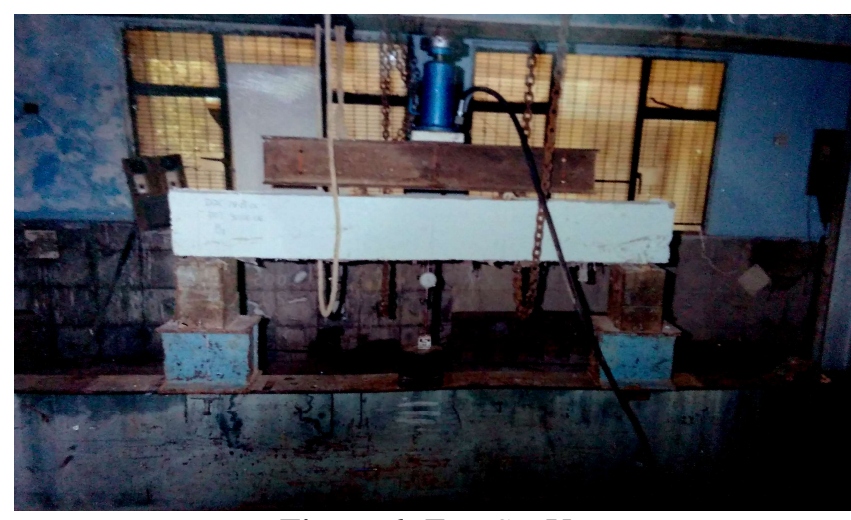

Figure 6- Test Set Up

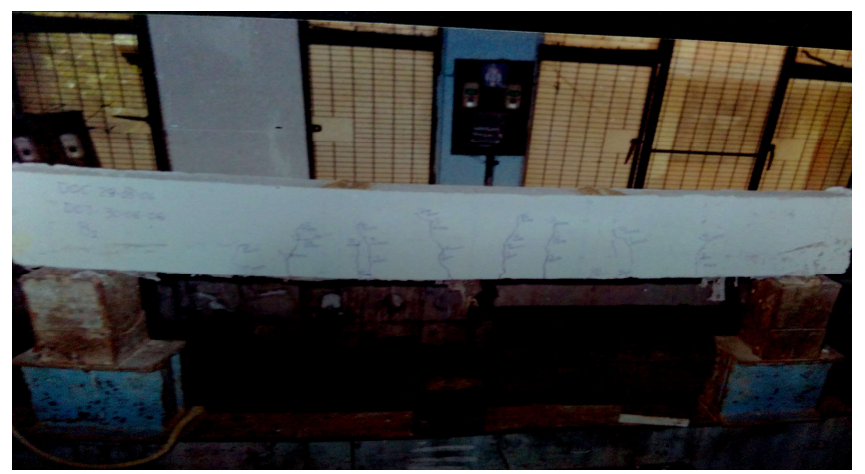

Figure 7- Crack Pattern in a Beam

\section{CONCLUSION}

The experimental programme is done on the study of deformation of Metakaolin fly ash and modified steel fiber reinforced concrete beams under shear. a grade of concrete taken was M25. A total of 12 beams were casted under various mixers namely $\mathrm{CC}, \mathrm{CFB}, \mathrm{CF}, \mathrm{CFF} \mathrm{CMK}$ and CMKF were tested under two point loading. Based on the results of the experimental investigation carried out in the scope of work the following conclusions are made:

1. Metakaolin generally requires addition of super plasticizer so that concrete could attain its desirable workability. Since metakaolin is found to consume water either by absorption or reaction.
2. It is found that compressive strength of metakaolin concrete increase its strength around $22 \%$ when compared with normal concrete and fly ash concrete. Addition of steel fiber to metakaolin concrete there is a gain of $42 \%$ in strength as compared to normal and fly ash concrete.

3. As regards to shear behavior of beams it is found that metakaolin reinforced concrete beams have higher loads with lesser deflections than normal and fly ash concrete. At first crack metakaolin concrete beams deflected by an average of $20 \%$ less as compared to normal concrete beams and with steel fiber concrete beams deflected by $25 \%$ less than that of normal concrete beams with steel fibers.

4. It is noticed that ultimate tensile strength is larger inn metakaolin concrete and metakaolin steel fiber reinforced concrete. However normal concrete and fly ash concrete is found to be less.

5. When a comparison was carried out for metakaolin, fly ash and normal concrete beams with and without steel fibers it was found that both have some number of shear cracks and also cracking spacing was lesser in metakaolin concrete compared to flyash and normal concrete.

6. The experimental result of first crack load obtained for all mixes are more than the theoretically predicted value.

7. All the beams failed as per the expected mode of failure of under reinforced section.

8. Addition of metakaolin significantly improves the performance of concrete matrix; hence metakaolin concrete can be used for specialized applications.

9. The addition of fibers increases the compressive strength, shear strength and effective in controlling shear cracks and increases shear capacity.

10. The mode of failure of reinforced concrete in shear changes from shear failure to flexural failure by increasing the fiber contents up to $0.75 \%$

\section{SCOPE FOR FUTURE WORK}

1. Comparison of flexural shear behavior of reinforced metakaolin concrete for other grades M30, M40, M50, of normal concrete with that of reinforced concrete with or without fibers.

2. To determine the flexural shear behavior of high strength reinforced metakaolin concrete.

3. Comparison of flexural behavior of reinforced metakaolin concrete with that of reinforced normal concrete and high strength concrete.

4. Crimped steel fibers with higher percentage $2 \%, 3 \%, 5 \%$ etc.

\section{REFERENCES}

[1]. Bai, J. and Wild, S (2002),"Investigation of The Temperature Change And Heat Evolution Of Mortar Incorporating PFA And Metakaolin", Cement and Concrete Composites, 24(2):210:209.

[2]. Bai, J. and Wild, S, Sabir B.B. and Kinuthia, J.M (1999),"Workability of Concrete Incorporating Pulverized 
Fuel Ash and Metakaolin", Magazine of Concrete Research, 51(3):207-216.

[3]. Caldarone, M.A, Gruber, K.A. and Burg, R.G.(1994), "High Reactivity Metakaoliln : A New Generation Mineral Admixture For High Performance Concrete", Concrete International, 16(11):37-40.

[4]. Dubey, A. and Banthia, N. (1998), "Influence of High Reactivity Metakaolin and Silica Fume on the Flexural Toughness of High Performance Steel Fiber Reinforced Concrete", ACI Materials Journal, 95(3):284-292.

[5]. Kathib, J.M, and Wild, S. (1996), "Pore Size Distribution of Metakaolin Paste", Cement and Concrete Research, 26(10):1545-1553.

[6]. Kathib, J.M, and Wild, S. (1998), "Sulphate Resistance of Metakaolin Mortar", Cement and Concrete Research, 28(1): 83-92.

[7]. Poon, C.S., Kou S.C and Lam. L (2000), "Pore Size Distribution of High Performance Metakaolin Concrete", Journal of Wuhan University of Technology Material Science Edition, 17(1): 42-46.

[8]. Poon, C.S., Kou, S.C., Wong, Y.L and Wong, R. (2001), "Rate Of Pozollanic Reaction of Metakaolin in High Performance Cement Pastes", Cement and Concrete Research, 31(9): 1301-1306.

[9]. Wild, S., Khatib, J. M., and Jones, A. (1996), "Relative Strength, Pozzolanic Activity and Cement Hydration in Superplasticised Metakaolin Concrete", Cement and Concrete Research, 26(10): 1537-1544.

[10]. Zhang, M. H., and Malhotra, V. M., (1995), "Characteristics of A Thermally Activated Alumino- Silicate Pozzolanic Material and Its Use in Concrete", Cement and Concrete Research, 1713-1725.

[11]. Bhanumathidaas, N and Kalidas, N., "Fly Ash: The Resource for Construction Industry", the Indian Concrete Journal, Vol 77. No. 4, April 2003, P.P.997-1004.

[12]. Book review,"High Performance, High Volume Fly Ash Concrete", The Indian Concrete Journal, Vol 77, April 2003, P.P.1040.

[13]. Erdogdu K and Turker P, "Effects Of Fly Ash Particle Size On Strength Of Portland Cement Fly Ash Mortars", Cement and Concrete Research, V. 28, No.9.1998, P.P.1040.

[14]. Ganesh, K., Rajagopal, K., Thagavel, K., Selvaraj, R and Saraswathi, V., "Rice Hush Ash- A Versatile Supplementary Cementitious Materials", ICI Jounal V.4 Jan March 2004, P.P 29-34.

[15]. Ganesh Babu, K., Siva Nageshwara Rao, "Efficiency of Fly Ash Concrete with Age", Cement and Concrete Research, V. 26, No.3, 1996, P.P.465-474.

[16]. Ganesh Babu, K, "Flexural Cracking in Concrete Structures", Journal of Structural Engineering, Vol. No.3, April 1997, P.P.17-30.

[17]. Haque, M. N and Kayali, O., "Properties Of High Strength Concrete Using A Fine Fly Ash", Cement and Concrete Research, V. 28, No.10, 1998, P.P.1445-1452.

[18]. Jan Olek and Sidney Diamond, "Proportioning Of Constant Paste Composition Fly Ash", ACI Material Journal, V. 86, No. 2, March-April 1989, P.P.159-166.

[19]. Janadhanam, R., Burns, F., Peindl R D, "Mix Design For Flow able Fly Ash Backfill Material", Journal of
Materials in Civil Engineering, ASCE Vol 4, August 1992, P.P.252-263.

[20]. Jain, L. K., Vishwanath, C. S., Reddi, S. A., Mahes Tandon, Lakshman, N., Sudhir Misra, Nori, V. V., Raina, S and Jand Momin, "Fly Ash In Cement And Concrete: What Expert Say", The Indian Concrete Journal, Vol. 77, April 2003, P.P.989-995. 